\title{
Hormone replacement therapy: prothrombotic vs. protective effects
}

\author{
Gordon D.O. Lowe \\ Department of Medicine, Royal Infirmary, University of Glasgow, UK
}

\begin{abstract}
Hormone replacement therapy (HRT) is associated with reduced risk of coronary heart disease (CHD) and stroke in observational studies; however the possibility of confounding by other risk factors requires prospective assessment of its risks and benefits in randomised controlled trials. The HERS trial of oral HRT in secondary CHD prevention observed an early increased risk of myocardial infarction (MI) and venous thromboembolism (VTE) with HRT: the latter risk has been confirmed by other prospective and case-control studies, and a past history of VTE or MI is now a contraindication to oral HRT. Other prospective randomised trials of HRT, $\mathrm{CHD}$ and stroke are in progress. Potential prothrombotic effects of oral HRT (but probably not transdermal HRT) include increased plasma factors VII and IX, activated protein $\mathrm{C}$ resistance and $\mathrm{C}$-reactive protein; and decreased antithrombin, protein $\mathrm{C}$ and $\mathrm{S}$, and tissue factor pathway inhibitor. Potential protective effects of HRT include decreased blood pressure, lipids, glucose intolerance, fibrinogen, viscosity and plasminogen activator inhibitor; and increased endothelial function. The overall balance of prothrombotic and protective effects varies with HRT preparations and individual women: and may be clarified by ongoing large randomised trials and case-control studies (and substudies of trials).
\end{abstract}

Copyright (C) 2002 S. Karger AG. Basel (c) 2002 S. Karger AG. Basel

$1424-8832 / 02 / 0326-0329 \$ 18.50 / 0$

\section{Introduction}

Menstruating women have a lower risk of coronary heart disease (CHD) than men, and this relative risk reduction is attenuated following the menopause. The "protective" effect of the menopause has been refuted (1). Observational studies suggest that HRT use is associated with reduced risk of CHD and mortality $(2,3)$, however such studies are biased due to confounding, in that HRT users have fewer CHD risk factors than non-users (4). Hence, the effects of HRT on CHD, stroke, and venous thromboembolism require prospective assessment of risks and benefits in randomised controlled trials.

Recent RCT results and a meta-analysis have shown that oral HRT use is associated with increased risk of venous thromboembolism (VTE) (5) as well as of stroke and breast cancer (6). Hence, physicians should not prescribe conventional oral HRT for women at increased risk of VTE, CHD or stroke. However, HRT reduces not only perimenopausal symptoms, but also the risk of osteoporosis and bone fractures, hence it is important to (a) establish the mechanisms through which conventional oral HRT might increase thrombotic risk (VTE, CHD, or stroke); and (b) establish whether or not alternative HRT preparations (e.g. low dose oral, or transdermal) or selective (o)estrogen receptor modulators (SERMs, e.g. raloxifene) may preserve their anti-symptomatic and anti-osteoporotic effects, while avoiding increase in thrombotic risk. 


\section{Prothrombotic effects}

\section{Increased coagulation factors}

Like COC preparations, oral HRT preparations increase the levels of several coagulation factors, especially factors VII and IX (7-9). Use of combined oestrogen-progestogen HRT reduces the increase in factor VII observed with unopposed oestrogen HRT $(9,10)$; but this is not explained by the differential effects of these HRT preparations on triglyceride levels (9). The increase in factor VII is similar for both fasting and postprandial plasma levels; but increases in activated factor VII are controversial $(11,12)$. While there is overall little epidemiological evidence that increased factor VII levels are associated with venous or arterial thrombosis, there is increasing interest in factor IX levels and thrombosis (13).

\section{Decreased coagulation inhibitors}

Like COC preparations, oral HRT preparations decrease the levels of several coagulation inhibitors, including antithrombin, proteins $\mathrm{S}$ and $\mathrm{C}$, and tissue factor pathway inhibitor (TFPI) (7-9; 13-15).

\section{Increased activated protein $C$ resistance}

A possible effect of oestrogens on activated protein $\mathrm{C}$ (APC) resistance was suggested by reports of increased APC resistance during pregnancy or COC use in the mid-1990's. In the first epidemiological study of APC resistance in a large sample of the general population, current HRT users were observed to have a similar level of increased APC resistance to current COC users $(16,17)$. In the same study, APC resistance was also associated with increasing age, obesity, and increased factor VIIIc levels (as well as the factor V Leiden mutation); hence we hypothesised that APC resistance was a potential common biological pathway through which all these risk factors for VTE might promote venous thrombosis $(16,17)$. Since 1997, we confirmed that APC resistance was associated with oral HRT use in a larger epidemiological study (18); while several other groups have confirmed that oral HRT use is associated with increased APC resistance in randomised controlled trials (19-21). One study of 12 patients with a "negative" result was not powered to detect an effect of oral HRT on APC resistance (22).

\section{Increased coagulation activation markers}

Studies of the effects of HRT on coagulation activation markers (e.g. prothrombin fragment $\mathrm{F} 1+2$, thrombinantithrombin (TAT) complexes, fibrin D-dimer) have shown variable results; this is not surprising in view of their skewed distributions, wide inter-and intra-individual variations, and the effect of venepuncture and ex vivo activation on $\mathrm{F} 1+2$ and TAT levels. However, overall oral HRT appears to increase circulating levels of these activation markers (7$9,12,14,15,17,23-25)$. To date, increased coagulation activation markers have been associated with increased APC resistance (21) - as in the general population (17) and during pregnancy (26) - and also with decreased TFPI levels in women with previous VTE (25).

\section{Increased $C$-reactive protein and proinflammatory cytokines}

Recent observational and prospective studies have shown that oral HRT is associated with increased plasma levels of Creactive protein, possibly due to oestrogen-induced upregulation of pro-inflammatory cytokines such as interleukin-6 (IL$6)$ or tumour necrosis factor alpha (TNF- $\alpha)(18,28-32)$.

Table 1. Potential prothrombotic and antithrombotic effects of oral HRT.

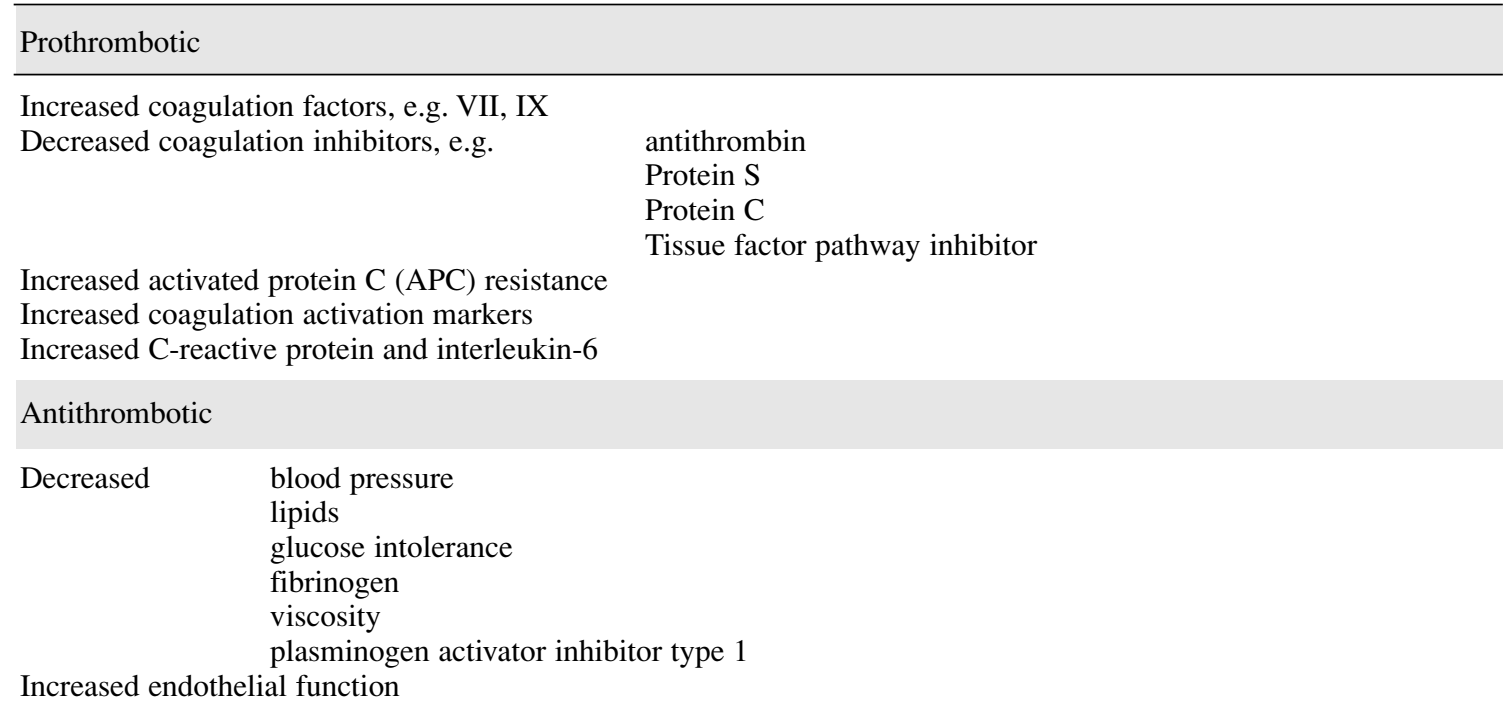




\section{Antithrombotic effects}

Several potential antithrombotic effects of HRT have been reported (Table 1), including decreases in blood pressure, lipids (including lipoprotein (a), glucose intolerance, and endothelial dysfunction $(6,7)$. Decreases in fibrinogen, viscosity and plasminogen activator type 1 (PAI-1) are most relevant to this review.

Several epidemiological studies have reported reduced fibrinogen levels in HRT users $(7,8)$; however such studies are susceptible to confounding (4) and more recent studies have not confirmed a fibrinogen-lowering effect $(12,14,23-25)$. Lower fibrinogen levels, as well as lower lipoprotein levels, may contribute to the lower plasma viscosity levels in HRT users $(18,33,34)$.

As with COC, oral HRT consistently lowers PAI-1 levels, as well as t-PA antigen levels (reflecting circulating PAI-1 t-PA complexes) $(7,8,12,18,22-24,35-37)$.

The relevance of these antithrombotic effects is unknown, because there is no evidence from RCT's that HRT reduces the risk of either arterial or venous thrombosis $(5,6)$.

\section{Which prothrombotic effects explain the prothrombotic risk of oral HRT?}

There is now no doubt that oral HRT increases the risk of VTE, by a factor of 2-3 $(5,6)$. Oral HRT increases plasma levels of factor IX and APC resistance; and decreases levels of coagulation inhibitors such as antithrombin $(17,18)$. Each of these variables has been associated with increased risk of VTE in case-control studies; and was shown to further increase the risk of VTE in HRT users (38). The supra-additive effect of
HRT use and APC resistance was confirmed to be due to the factor $\mathrm{V}$ Leiden mutation in a subsequent report from the same study $(38,39)$ and in a separate study $(40)$. Hence it seems reasonable to suggest that HRT use increases the risk of VTE by multiple prothrombotic effects, including its effect on APC resistance. In view of the possible effects of inflammation on VTE, the supra-additive association of plasma CRP levels with VTE and HRT use (42) is also of interest.

The prothrombotic and proinflammatory effects of oral HRT may also be relevant to the increased risk of stroke (and possibly of coronary heart disease) associated with its use in randomised controlled trials (6). The increased risk of stroke may partly reflect "paradoxical" thromboembolism from the venous circulation through right-to-left intracardiac shunts (e.g. patent foramen ovale, atrial septal defect). The relevance of the prothrombotic and proinflammatory effects of oral HRT to arterial thrombosis requires further study (32).

\section{Transdermal versus oral HRT}

Overall, the literature suggests that transdermal HRT does not induce the same prothrombotic and proinflammatory effects as oral HRT $(7-8,12,18,23)$. This probably reflects the lack of a "first-pass" effect of oral HRT on hepatic metabolism (18). A preliminary report from the ESTHER case-control study of HRT and VTE in France suggests that transdermal HRT is not associated with VTE, in contrast to oral HRT (43). Transdermal HRT may therefore be considered in women who are at increased risk of VTE (44). The relative risks of arterial thromboembolism for transdermal versus oral HRT require further study.

\section{References}

1. Tunstall-Pedoe $\mathrm{H}$, Cardiovascular risk in women: the cardidogist's perspective. QJM 2000; 93:388

2. Psaty BM, Heckbert SR, Atkins D, Siscovick DS, Koepsell TD, Wahl PW, Longstreth WT Jr, Weiss NS, Wagner EH, Prentice R. A review of the association of estrogens and progestins with cardiovascular disease in postmenopausal women. Arch Intern Med 1993; 153: 14211427

3. Grady D, Rubin SM, Petitti DB, Fox CS, Black D, Ettinger B, Ernster VL, Cummings SR. Hormone therapy to prevent disease and prolong life in postmenopausal women. Ann Intern Med 1992; 117: 1016-1037

4. Posthuma WF, Westendorp RG, Vandenbroucke JP. Cardioprotective effect of hormone replacement therapy in postmenopausal women: is the evidence biased? BMJ 1994; 308: 1268-1269

5. Rosendaal FR, Helmerhorst FM, Vandenbroucke JP. Female hormones and thrombosis. Arterioscler Thromb Vasc Biol 2002; 22: 201-210

6. Beral V, Banks E, Reeves G. Evidence from randomised trials on the long-term effects of hormone replacement therapy. Lancet 2002; 360: $942-944$

7. Lowe GDO. Coagulation, fibrinolysis and hormone replacement therapy. In Shaw, R.W. (ed). Oestrogen Deficiency. Causes and Consequences. Carnforth, UK: Parthenon, 1996; 29-44

8. Meade TW. Hormone replacement therapy and haemostatic function. Thromb Haemost 1997; 78: 765-769

9. Woodward, M., Lowe, G.D.O., Rumley, A., Tunstall-Pedoe, H., Philippou, H., Lane, D.A., Morrison, C.E..Epidemiology of coagulation factors, inhibitors and activation markers: The Third Glasgow MONICA Survey. II. Relationships to cardiovascular risk factors and prevalent cardiovascular disease. British Journal of Haematology, 1997, 97, 785-797.
10. Medical Research Council, General Practice Research Framework. Randomised comparison of oestrogen versus oestrogen plus progestogen hormone replacement therapy in women with hysterectomy. BMJ 1996; 312: 473-478

11. de Valk-de Roo GW, Stehouwer CDA, Emeis JJ, Nicolaas-Merkus A, Netelenbos C. Unopposed oestrogen increases total plasma factor VII, but not active factor VII. Thromb Haemost 2000; 84: 968-72

12. Vehkavaava S, Silveira A, Hakala-Ala-Pietila T, Virkamaki A, Hovalta O, Hamsten A, Taskinen M-R, Yki-Jarvinen H. Effects of oral and transdermal oestrogen replacement therapy on markers of coagulation, fibrinolysis, inflammation and serum lipids and lipoproteins in postmenopausal women. Thromb Haemost 2001; 85: 619-625

13. Lowe GDO. Factor IX and thrombosis.British Journal of Haematology, 2001, 115: 507-513

14. Lowe, G.D.O., Rumley, A., Woodward, M. 
Morrison, C.E., Philippou, H., Lane, D.A., Tunstall-Pedoe, $\mathrm{H}$. Epidemiology of coagulation factors, inhibitors and activation markers: The Third Glasgow MONICA Survey. I. Illustrative reference ranges by age, sex and hormone use. British Journal of Haematology, 1997, 97, 775-784.

15. Peverill RE, Teede HJ, Smolich JJ, Malan E, Kotsopoulos D, Tipping PG, McGrath BP. Effects of combined oral hormone replacement therapy on tissue factor pathway inhibitor and factor VII. Clin Sci Mol Med2001; 101: 93-99

16. Lowe, G.D.O., Rumley, A., Woodward, M., Reid, E. Oral contraceptives and venous thromboembolism. Lancet, 1997, 349, 1623 (letter).

17. Lowe, G.D.O., Rumley, A., Woodward, M., Reid, E., Rumley, J..

Activated protein $\mathrm{C}$ resistance and the $\mathrm{FV}$ : R506Q mutation in a random population sample: associations with cardiovascular risk factors and coagulation variables. Thrombosis and Haemostasis, 1999; 81: 918-924

18. Lowe G.D.O., Upton M.N., Rumley A., McConnachie A., O'Reilly D.S.J., Watt G.C.M. Different effect of oral and transdermal hormone replacement therapies on Factor IX, APC resistance, t-PA, PAI and C-reactive protein: a cross-sectional population survey. Thrombosis and Haemostasis, 2001; 86: 550556

19. Hoibraaten E, Mowinckel M-C, de Ronde H, Bertina RM, Sandset PM. Hormone replacement therapy and acquired resistance to activated protein C: results of a randomised, double-blind, placebo-controlled trial. $\mathrm{Br} \mathrm{J}$ Haematol 2001; 115: 415-420

20. Demirol A, Baykal C, Kirazli S, Ayhan A. Effects of hormone replacement on haemostasis in spontaneous menopause. Menopause 2001; 8: 135-140

21. Post MS, Rosing J, van der Mooren MJ, Zweegman S, van Baal WM, Kenemans P, Stehouwer CDA. Increased resistance to activated protein $\mathrm{C}$ after short-term oral hormone replacement therapy in healthy postmenopauseal women. Br J Haematol 2002; 119: 1017-1023

22. Douketis JD, Gordon M, Johnston M, Julian JA, Adachi JR, Ginsberg JS. The effects of hormone replacement therapy on thrombin generation, fibrinolysis inhibition, and resistance to activated protein C. Thromb Res 2000; 99: 25-34

23. Scarabin P-Y, Alhenc-Gelos M, Plu-Bureau G,
Taisre P, Agher R, Aiach M. Effects of oral and transdermal oestrogen/progesterone regimens on blood coagulation and fibrinolysis in postmenopausal women. Arterioscler Thromb Vasc Biol 1997; 17: 3071-3078

24. Teede HJ, McGrath BP, Smolick JJ, Malan E, Kotsopoulos D, Liang Y-L, Peverill RE. Postmenopausal hormone replacement therapy increases coagulation activity and fibrinolysis. Arterioscler Thromb Vasc Biol 2000; 20: 1404-1409

25. Hoibraaten E, Qvigstad E, Anderson TO, Mowinckel M-C, Sandset P-M. The effects of hormone replacement therapy (HRT) on haemostatic variables in women with previous venous thromboembolism-results from a randomised, double-blind, clinical trial. Thromb Haemost 2001; 85: 775-781

26. Clark $P$ et al. Lancet 2001

27. Van Wijk MJ, Boer K, Berckmans RJ, Meijers JCM, van der Post JAM, Sturk A, Van Barel E, Nieuwland R. Enhanced coagulation activation in preeclampsia: the role of APC resistance, microparticles and other plasma constituents. Thromb Haemost 2002; 88: 415-420

28. van Baal WM, Kenemans P, van der Mooren $\mathrm{MJ}$, et al, Increased C-reactive protein levels during short term hormone replacement therapy in healthy post- menopausal women. Thromb Haemost 1999; 81: 925-928

29. Ridker PM, Hennekens CH, Rifai N, Buring JE, Manson JE. Hormone replacement therapy and increased plasma concentration of Creactive protein. Circulation 1999; 100: 713 716

30. Cushman M, Legault C, Barrett-Connor E, et al. Effect of postmenopausal hormones on inflammation-sensitive proteins: the Postmenopausal Estrogen/Progestin Interventions (PEPI) Study. Circulation 1999; 100:717-722

31. Brooks-Asplund EM, Tupper CE, Daun JM, Kenney WL, Cannon JG. Hormonal modulation of interleukin 6, tumour necrosis factor and associated receptor secretion in postmenopausal women. Cytokine 2002; 19: 193 200

32. Pradhan AD, Manson JE, Rossouw JE, Siscovick DS, Mouton CP, Rifai N, Wallace RB, Jackson RD, Pettinger MB, Ridker PM. Inflammatory biomarkers, hormone replacement therapy, and incident coronary heart disease. JAMA 2002; 288: 980-987

33. Rosenson RS, Tangney CC, Mosca LJ. Hormone replacement therapy improves cardiovascular risk by lowering plasma viscosity in postmenopausal women. Arterioscler Thromb Vasc Biol 1998; 18: 1920-1905

34. Frohlich et al Br J Haematol 2000

35. Shahar E, Folsom AR, Salomaa VV, Stinson VL, McGovern PG, Shimakawa T, Chambless LE, Wu KK. Relation of hormone replacement therapy to measures of plasma fibrinolytic activity. Circulation 1996; 93: 1970-1975

36. Cushman M, Meilahn EN, Psaty BM, Kuller LH, Dobs AS, Tracy RP. Hormone replacement therapy, inflammation, and haemostasis in elderly women. Arterioscler Thromb Vasc Biol 1999; 19: 893-899

37. Koh KK, Horne MK III, Cannon RO III. Effects of hormone replacement therapy on coagulation, fibrinolysis, and thrombosis risk in postmenopausal women. Thromb Haemost 1999; 82: 626-633

38. Lowe, G.D.O., Woodward, M., Vessey, M.P., Rumley, A., Gough, P., Daly, E. Thrombotic variables and risk of idiopathic venous thromboembolism in women aged 45-64 years: relationships to hormone replacement therapy. Thrombosis and Haemostasis, 2000; 83: 530535

39. Rosendaal FR, Vessey M, Rumley A, Daly E, Woodward M, Helmerhorst FM, Lowe GDO. Hormonal replacement therapy, prothrombotic mutations and the risk of venous thrombosis. British Journal of Haematology, 2002; 116: 851-854

40. Herrington DM, Vittinghoff E, Howard TD, Major DA, Owen J, Reboussin DM, Bowden D, Bittner V, Simon JA, Grady D, Hulley SB. Factor V Leiden, hormone replacement therapy, and risk of venous thromboembolic events in women with coronary disease. Arterioscler Thromb Vasc Biol 2002; 22: 1012-1017

41. Vandenbroucke JP, Koster T, Briet E, Reitsma $\mathrm{PH}$, Bertina RM, Rosendaal FR. Increased risk of venous thrombosis in oral-contraceptive users who are carriers of factor V Leiden mutation. Lancet 1994; 344: 1453-1457

42. Lowe G.D.O., Rumley A., Woodward M., Vessey M. C-reactive protein, idiopathic venous thrombo-embolism and hormone replacement therapy.

Thrombosis and Haemostasis, 2000; 84: 730741

43. Scarabin, Prophylaxis of venous thromboembolism. A national clinical guideline. (SIGN guideline 62) Scottish Intercollegiate Guidelines Network (SIGN), Edinburgh, 2002 